\title{
Study of the Effect of Nigella Sativa Oil and Its Loaded Nanoparticles on Acute Cystic Echinoncoccosis in Experimentally Infected Mice
}

I.M.Nagati ${ }^{1}$, I.R.Ali ${ }^{2}$, N.S.Aly ${ }^{1}$, H.S.Ali ${ }^{1}$, M.M.fawzy ${ }^{1}$ and S.M.kishik ${ }^{1}$

${ }^{1}$ Parasitology Dept., Faculty of Medicine, Benha Univ., Benha, Egypt

${ }^{2}$ Immunoparasitology Dept., Theodor Bilharz Research institute, Imbaba, Giza, Egypt

E-Mail:dr.mahamamdouh@gmail.com

\begin{abstract}
Cystic echinococcosis (CE) are commonly found in the viscera of affected hosts. There were different methods of treatment of CE. Surgery is one of these methods by using different scolicidal agents for inactivation of protoscoleces, but they have side effects. Natural herbal extract are safe and have many pharmacological uses in different fields. Nigella sativa may be a standout amongst these natural extricate. Those exhibit contemplate meant should assess viability about nigella sativa Possibly alone alternately done mix with Albendazole What's more At they stacked around Chitosan nanoparticles once murine hydatid growth. Swiss pale skinned person mice were utilized within this consider Furthermore arranged under eight aggregations. The pill might have been administrated two months post spoiling to in turn two months span. After sacrifaction the appraisal of size and weight of the cysts were finished. The effects of this contemplate uncovered that, there were noteworthy viability altogether dealt with Assemblies $\mathrm{p}<0.05$ and profoundly critical for Assemblies stacked for chitosan nanoparticles in examination to control gathering. Clinched alongside conclusion, nigella sativa need beneficial impact to hydatid growth treatment Possibly alone alternately in mix. Stacking for pills on chitosan nanoparticles expanded those pills viability with the goal chitosan nanoparticles have possibility impact to help.
\end{abstract}

Keywords: Hydatid, Albendazole, Nigella sativa, Chitosan nanoparticles.

\section{Introduction}

Ce brought about Eventually Tom's perusing the metacestode (larval) stage about e. Granulosus. It may be at present a paramount general population wellbeing worry over numerous nations of the world, for example, the mediterranean and south america nations Concerning illustration those ailment influences people Also down home animals including cattle, sheep, camels, pigs, horses also how [1].

In spite of the fact that those ailment is accounted for anyplace in the world, its recurrence is higher clinched alongside lesquerella produced countries, making harm of the wellbeing What's more financial structures about groups [2].

Ce will be discovered mostaccioli in the liver What's more lungs, Also here and there in the kidneys, spleen, bones, cerebrum Furthermore other organs [3].

Medication routes for ce incorporate surgery, percutaneous intervention, medication therapy, and "lookout Furthermore sit tight [4]. Indeed though, surgery stays the fundamental medication to ce on account of there is incredible repeat rate Also chemotherapy can't prompt finish cure in inoperable instances [5]. With move forward brings about patients for ce who will experience surgery, pharmacological medicine may be acknowledged Furthermore Albendazole chemotherapy will be those grade medicinal medication to Right away [6]. A few plant extracts, for example, garlic and olive leaf beet extracts bring been assessed Concerning illustration scolicidal operators As opposed to utilizing chemotherapy over conjunction for surgery [7]. In this study we attempted will assess part of n. Sativa oil Possibly as monotherapy or done blending for Albendazole ahead hydatid growth for test mice and the viability from claiming chitosan nanoparticles as pill transporter to both $\mathrm{n}$. Sativa What's more Albendazole Also their consolidation.

\section{Materials and methods}

The field work was conducted in the Schistosome Biological Supply Center (SBSC), Theodor Bilharz Research Institute (TBRI), Giza, Egypt between January and May.

\section{Parasites}

Protoscoleces collection: Hydatid cysts were obtained from lung of sheep at El-Warrak slaughter house in Cairo, Egypt. E.granulosus protoscoleces were obtained by aseptic puncture of the cysts [8].

\section{protoscoleces Preparation}

Preparation of the protoscoleces might have been as stated by [9]. Shortly, those hydatid liquid might have been aspirated from rich sheep pulmonary cysts under aseptic states. The liquid might have been centrifuged and the silt holding protoscoleces might have been washed for sterile phosphate support saline (PBS) (pH7. 2-7. 4 ,Sigma concoction Company, St. Louis, MO, USA) supplemented with $30 \mathrm{mg} / \mathrm{mL}$ gentamicin (GIBCO-BRL existence Technology, NY).

Viability assay: Protoscoleces viability might have been confirmed through staining for $0.1 \%$ eosin. An answer Hosting $0.1 \mathrm{mg}$ for eosin staining powder might have been included on $100 \mathrm{ml}$ water to structure a $0.1 \%$ $(w / v)$ fixation stock result. Those protoscoleces viability might have been assessed microscopically by including $10 \mu \mathrm{l}$ for eosin stock answer for $10 \mu \mathrm{L}$ of protoscoleces for 15 minutes. The unstained Also moving protoscoleces were viewed as Similarly as feasible same time the stained protoscoleces were viewed as dead [10]. The sum specimens needed viability $>95 \%$ at the long run from claiming analyze.

Mice infection: every mouse might have been contaminated Eventually Tom's perusing almost 1000 
feasible protoscoleces suspended over $500 \mu$ l about sterile pbs by intra perithelium vaccination [11].

\section{Drugs and herbal extract}

a) N.sativa oil: it was obtained as soft gelatin capsules (450 mg) (Pharco Pharmaceutical, Alexandria, Egypt). The capsule was opened, and oil was dissolved in $2 \mathrm{ml}$ distilled water (Sharafeldin, 2015)[12] to obtain dose of $1.14 \mathrm{gm} / \mathrm{kg}$ [13].

B) Albendazole: Albendazole was available as bendax tablets and suspension forms. In this study we used the bendax suspension form $(100 \mathrm{mg} / 5 \mathrm{ml})$ produced by Sigma medical company. Albendazole was given in a dose of $200 \mathrm{mg}$ [14].

c) Nigella sativa oil\& Albendazole loaded on chitosan nanoparticles:-

Albendazole loaded on chitosan nanoparticles was given in a dose of $200 \mathrm{mgl} \mathrm{kg}$ and $\mathrm{N}$. sativa oil loaded on chitosan nanoparticles was given in a dose of $1.14 \mathrm{gm} / \mathrm{kg}$.

\section{Preparation of Chitosan nanoparticles}

The synthesis procedures were carried out according to the ionotropic gelation technique by 15$]$.

\section{Mice grouping and experimental design}

Pathogen-free adult male Swiss albino mice , six to eight weeks old weighing 25-30 gm inbred at Schistosome Biological Supply Center (SBSC), Theodor Bilharz Research Institute (TBRI), Giza, Egypt was used in throughout this study. Animals were housed in TBRI, Experimental Animal Unit. The mice were maintained under standard laboratory care $(25 \mathrm{C}$, with a relative humidity of 40-60\%, normal diet of commercial pellets and potable water.

A total of 96 laboratory-bred male Swiss albino mice were used in this study and classified into 8 groups (12 mice each).

Group (1): non infected non treated (normal)

Group (2): infected non treated.

Group (3): infected and treated with albendazole (dose $200 \mathrm{mg} / \mathrm{kg}$ ).

Group (4): :infected and treated with N.sativa oil (dose $1.14 \mathrm{gm} / \mathrm{kg}$ ).

Group (5) :infected and treated with N.sativa oil $($ dose $1.14 \mathrm{gm} / \mathrm{kg}$ ) and Albendazole (dose $200 \mathrm{mg} / \mathrm{kg})$.

Group(6): infected and treated with Albendazole loaded on chitosan nanoparticles (dose $200 \mathrm{mg} / \mathrm{kg}$ ).

Group(7): infected and treated with N.sativa oil loaded on chitosan nanoparticles (dose $1.14 \mathrm{gm} / \mathrm{kg}$ ).

Group(8):_infected and treated with Albendazole loaded on chitosan nanoparticles (dose $200 \mathrm{mg} / \mathrm{kg}$ ) and N.sativa oil loaded on chitosan nanoparticles (dose $1.14 \mathrm{gm} / \mathrm{kg}$ ).

Drugs were administered orally to mice via tube feeding starting 2 months post protoscoleses inoculation (Urrea-Paris et al. 2002) [16] for more 2 months (Labsi et al.2016) [8].

Evaluation of drugs efficacy

\section{parasitological}

Evaluation for growth advancement at the wind of the medication time. Animals were euthanized four months post contamination, and necropsy might have been therefore conveyed out. The peritoneal might have been opened precisely What's more diverse organs were inspected. Those hydatid cysts were photographed Eventually Tom's perusing An advanced even now Polaroid Also Eventually Tom's perusing the scaled ruler utilizing adobe Photoshop CS3; those sizes of the cysts were measured. After the cysts were deliberately removed, the weight might have been dead set by utilizing a scientific equalization. Through the utilization of the accompanying formula, those viability rate of medicines for hydatid growth development restraint might have been computed [17]. Treatment efficacy=

$$
\frac{C-T}{C} \times 100 \%
$$

Where $\mathrm{C}$ is the mean cyst weight in the infected nontreated control group and

$\mathrm{T}$ is the mean cyst weight in the treated group.

\subsection{Statistical analysis}

These information were tabulated, coded afterward investigated utilizing the PC program SPSS adaptation 16 (Chicago, IL, USA). Student's t-test used to think about the intend of two gatherings about measurable (parametric) information. Those $\mathrm{p}$ worth $<0.05$ might have been viewed as statistically critical Furthermore $\mathrm{p}$ quality <0. 0001 might have been recognized Exceptionally huge On the whole analyses.

Moral considerations: every last one of creature investigations were performed as stated by the decides of the logical examination moral Committee, staff of drug Benha college. Similarly as well, creature taking care of and every one methods were finished in understanding for those around the world moral rules.

\section{Results}

Concerning illustration indicated clinched alongside table1, there might have been critical diminishment in the average quality for hydatid growth span in aggregations approached with Albendazole, n. Sativa oil What's more joined together NSO \& Albendazole (ABZ) ) in examination should aggregation $2(p<0$. 05) What's more complete nonattendance for hydatid growth for gatherings dealt with for Albendazole, NOS, joined NOS \& Albendazole stacked around chitosan nanoparticles,in table 2 there might have been statistically critical distinction in the average quality about hydatid growth weight the middle of aggregations $3 \& 4 \& 5$ and gathering $2(\mathrm{p}<0.05)$ and there might have been helter skelter statistically critical Contrast $\mathrm{p}<0.005$ over Assemblies $6 \& 7$ Furthermore 8 in examination on group2. On table 3 there might have been diminishment in the imply growth weight altogether aggregations approached in examination with one assembly 2 . Those percent arrived at $100 \%$ On the whole gatherings stacked for chitosan nanoparticles, Also arrived at $47 \%, 34 \%$ and $57 \%$ to bunches 3 ,4and 5 respectivly. 
Table (1) Effect of herbal treatment with NSO \&Albendazole and their loaded chitosan nanoparticles (nano.) on hydatid cyst size in liver of experimentally infected mice

\begin{tabular}{|c|c|c|c|c|c|c|c|c|c|c|}
\hline Groups & $\begin{array}{c}(1) \\
\text { Non } \\
\text { infected non } \\
\text { treated }\end{array}$ & $\begin{array}{c}(2) \\
\text { Infected } \\
\text { untreated }\end{array}$ & $\begin{array}{c}\text { (3) } \\
\text { ABZ }\end{array}$ & $\begin{array}{l}\text { (4) } \\
\text { NSO }\end{array}$ & $\begin{array}{c}\mathbf{5}) \\
\text { ABZ } \\
+ \\
\text { NSO }\end{array}$ & $\begin{array}{l}\text { (6)ABZ loaded } \\
\text { on chitosan } \\
\text { nano. }\end{array}$ & $\begin{array}{c}\text { NSO } \\
\text { NSO } \\
\text { loaded on } \\
\text { chitosan } \\
\text { nano. }\end{array}$ & $\begin{array}{c}(8) \\
\text { ABZ Loaded } \\
\text { on chitosan } \\
\text { nano.+ NSO } \\
\begin{array}{c}\text { Loaded with } \\
\text { nano. }\end{array} \\
\end{array}$ & $\begin{array}{c}\text { Statistical } \\
\text { test }\end{array}$ & $\begin{array}{c}P \\
\text { value }\end{array}$ \\
\hline $\begin{array}{l}\text { Cyst Size } \\
(\mathrm{mm}) \\
\text { Median } \\
\text { IOR }\end{array}$ & $0.00 .0-0.0$ & $\begin{array}{c}5.353 .99- \\
5.89\end{array}$ & $\begin{array}{l}1.20 .6 \\
6-1.7\end{array}$ & $\begin{array}{c}1.60 . \\
98- \\
2.25\end{array}$ & $\begin{array}{c}0.930 \\
.791 . \\
61\end{array}$ & $0.00 .0-0.0$ & $\begin{array}{c}0.00 .0- \\
0.0\end{array}$ & $0.00 .0-0.0$ & $\begin{array}{l}\mathrm{KW}= \\
47.91\end{array}$ & $\begin{array}{c}<0.001 \\
* *\end{array}$ \\
\hline P1 & & $<0.001 * *$ & $\begin{array}{c}<0.00 \\
1 * *\end{array}$ & $\begin{array}{l}<0.0 \\
01^{* *}\end{array}$ & $\begin{array}{c}<0.00 \\
1 * *\end{array}$ & 1.0 & 1.0 & 1.0 & & \\
\hline $\mathbf{P 2}$ & & & $0.01 *$ & $\begin{array}{c}0.01 \\
4^{*}\end{array}$ & $\begin{array}{c}0.011 \\
*\end{array}$ & $0.002 * *$ & $0.004 * *$ & $0.002 * *$ & & \\
\hline
\end{tabular}

-ABZ=albendazole. $\quad-\mathrm{NSO}=$ nigella sativa oil. - nano.= nanoparticle $-\mathrm{IQR}=$ inter-quartile range. $-\mathrm{KW}=\mathrm{Kruskal}-\mathrm{wallis}$. $-\mathrm{P} 1=$ difference between non infected non treated group and others. $-\mathrm{P} 2=$ difference between infected nontreated group and others.

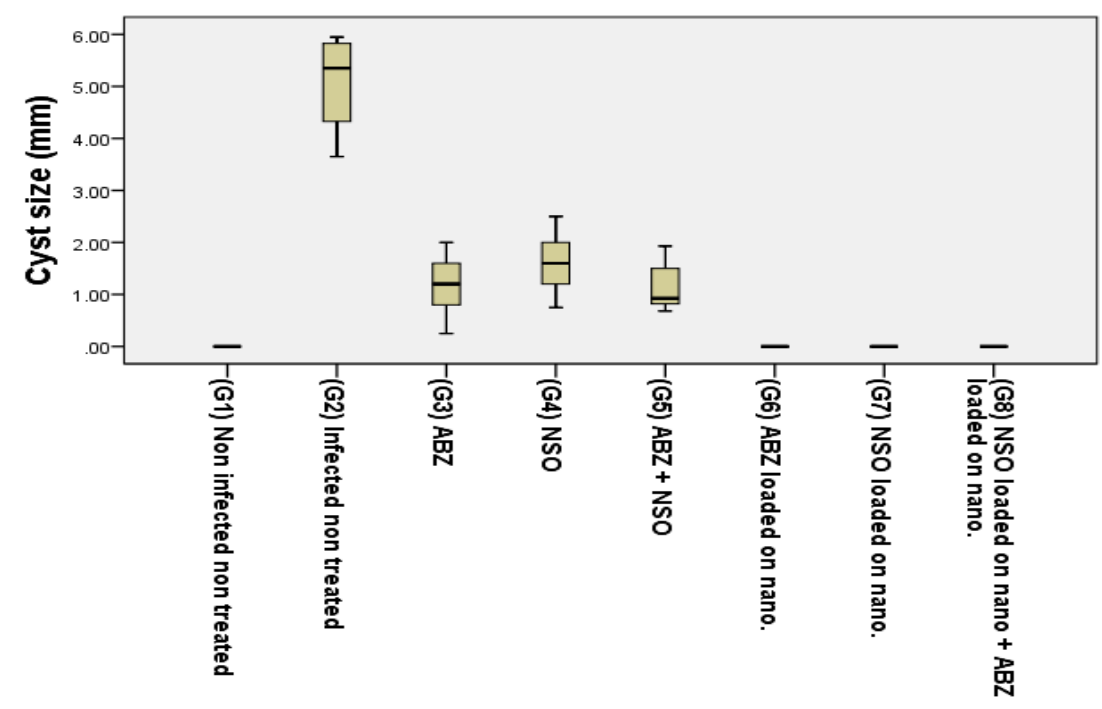

Fig (1) Comparison between different groups regarding hydatid cyst size.

Table (2) Effect of herbal treatment with NSO \& Albendazole and their loaded chitosan nanoparticles on hydatid cyst weight in liver of experimentally infected mice .

\begin{tabular}{|c|c|c|c|c|c|c|c|c|c|c|}
\hline Groups & (G1) & (G2) & (G3) & (G4) & (G5) & (G6) & (G7) & (G8) & $\begin{array}{c}\text { Statistical } \\
\text { test }\end{array}$ & P value \\
\hline \multirow{3}{*}{$\begin{array}{l}\text { Cyst } \\
\text { weight } \\
\text { (g) } \\
\text { Median } \\
\text { IQR }\end{array}$} & $\begin{array}{c}\text { Non } \\
\text { Infected } \\
\text { non } \\
\text { treated }\end{array}$ & $\begin{array}{l}\text { Infected } \\
\text { untreated }\end{array}$ & $\mathrm{ABZ}$ & NSO & $\begin{array}{c}\mathrm{ABZ} \\
+ \\
\mathrm{NSO}\end{array}$ & $\begin{array}{c}\text { ABZ } \\
\text { loaded on } \\
\text { chitosan } \\
\text { nano. }\end{array}$ & $\begin{array}{c}\text { NSO } \\
\text { loaded on } \\
\text { chitosan } \\
\text { nano. }\end{array}$ & $\begin{array}{c}\text { ABZ Loaded } \\
\text { on chitosan } \\
\text { nano.+ NSO } \\
\text { loaded on } \\
\text { chitosan } \\
\text { nano. }\end{array}$ & & \\
\hline & $\begin{array}{c}0.00 .0- \\
0.0\end{array}$ & $\begin{array}{c}0.750 .66 \\
-0.80\end{array}$ & $\begin{array}{c}0.430 \\
.21- \\
0.49\end{array}$ & $\begin{array}{c}0.540 .2 \\
6-0.62\end{array}$ & $\begin{array}{c}0.320 \\
.15- \\
0.44\end{array}$ & $\begin{array}{c}0.00 .0- \\
0.0\end{array}$ & $\begin{array}{c}0.00 .0- \\
0.0\end{array}$ & $0.00 .0-0.0$ & $\mathrm{KW}=48.05$ & $<0.001 * *$ \\
\hline & P1 & $\begin{array}{c}<0.001 * \\
*\end{array}$ & $\begin{array}{c}<0.00 \\
1 * *\end{array}$ & $\begin{array}{c}<0.00 * \\
*\end{array}$ & $\begin{array}{l}<0.0 \\
1 * *\end{array}$ & 1.0 & 1.0 & 1.0 & & \\
\hline $\mathbf{P 2}$ & & & $0.01 *$ & $0.019^{*}$ & $0.01 *$ & $0.002 * *$ & $0.004 * *$ & $0.002 * *$ & & \\
\hline
\end{tabular}

-P1=difference between non infected non treated group \& others.

-P2= difference between infected non treated group\& others. 


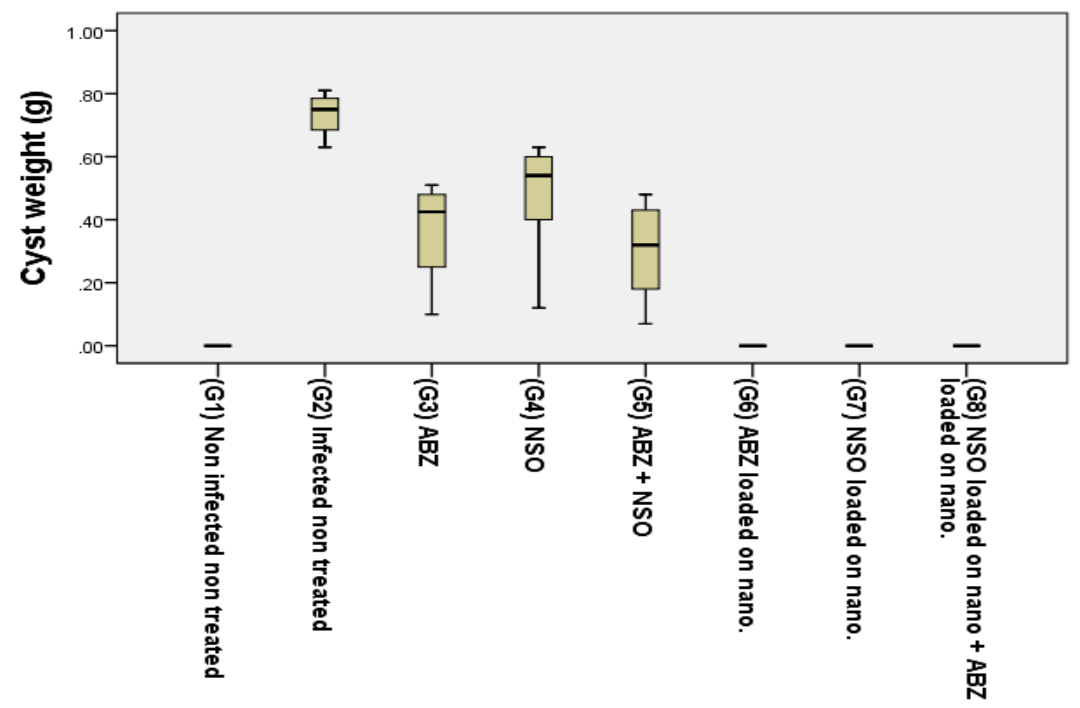

Fig (2) Comparison between different groups regarding hydatid cyst weight

Table (3) Effect of herbal treatment with NSO \&Albendazole and their loaded chitosan nanoparticles on hydatid cyst growth inhibition.

\begin{tabular}{|c|c|c|c|c|c|c|c|c|c|c|}
\hline Groups & (G1) & (G2) & (G3) & (G4) & (G5) & (G6) & (G7) & (G8) & $\begin{array}{c}\text { Statist } \\
\text { ical } \\
\text { test } \\
\end{array}$ & $\begin{array}{c}P \\
\text { value }\end{array}$ \\
\hline & $\begin{array}{c}\text { Non } \\
\text { Infected } \\
\text { non } \\
\text { treated }\end{array}$ & $\begin{array}{c}\text { Infected } \\
\text { untreated }\end{array}$ & $\mathrm{ABZ}$ & $\mathrm{NSO}$ & $\begin{array}{c}\mathrm{ABZ} \\
+ \\
\mathrm{NSO}\end{array}$ & $\begin{array}{c}\text { ABZ } \\
\text { loaded } \\
\text { on } \\
\text { chitosan } \\
\text { nano. }\end{array}$ & $\begin{array}{c}\text { NSO } \\
\text { loaded } \\
\text { on } \\
\text { chitosan } \\
\text { nano. }\end{array}$ & $\begin{array}{c}\text { ABZ } \\
\text { Loaded On } \\
\text { chitosan } \\
\text { nano. }+ \\
\text { NSO loaded } \\
\text { on chitosan } \\
\text { nano. }\end{array}$ & & \\
\hline $\begin{array}{l}\text { Cyst } \\
\text { weight } \\
\text { (g) } \\
\text { Mean } \\
\pm \text { SD }\end{array}$ & $\begin{array}{c}0.00 .0- \\
0.0\end{array}$ & $0.7 \pm 0.08$ & $0.37 \pm 06$ & $\begin{array}{c}0.46 \pm 02 \\
1\end{array}$ & $\begin{array}{c}0.30 \pm \\
0.16\end{array}$ & $0.0 \pm 0.0$ & $0.0 \pm 0.0$ & $0.0 \pm 0.0$ & $\begin{array}{c}\mathrm{KW}=3 \\
9.7\end{array}$ & $\begin{array}{l}<0.001 \\
\quad * *\end{array}$ \\
\hline $\begin{array}{l}\text { Treatmen } \\
\text { t efficacy }\end{array}$ & - & - & $47 \%$ & $34 \%$ & $57 \%$ & $100 \%$ & $100 \%$ & $100 \%$ & & \\
\hline
\end{tabular}

\section{Discussion}

Albendazole (ABZ) will be the The majority broad and successful burrowing little creature parasitic medication regardless for alveolar echinococcosis medicine. However, owing will its insufficient solvency for water and the coming about poor intestinal absorption Eventually Tom's perusing oral administration, ABZ need low oral bioavailability, plasma level, and liver circulation [18]. Moreover, ABZ normally includes the deep rooted uptake for vast doses of the drug, making the pre-vention about huge numbers extreme unfriendly medication impacts was troublesome [19].

Done later years, researcher's deliberations bring kept tabs for new ABZ formulations that prompt exceptional tissue What's more organ penetration, including liposomes, biodegradable microspheres, Furthermore polymer conjugates. In this way the pill will be discharged for prolonged periods of time, enhancing those restorative impact [24].

N. Sativa seeds need totally restorative impacts Also bring been appeared for need critical impacts against a significant number helminth infections. Mostly, the restorative profits of $\mathrm{n}$. Sativa would because of its lavishness clinched alongside Thymoquinone (TQ), which is An real animated constituent. To investigations centering on antiparasitic impacts [20]. It need been discovered that separate extracts of $\mathrm{n}$. Sativa, and also TQ, have An powerful anthelmintic activity against fasciola gigantica [21] ,also need impact against trichinella spiralis spoiling Also expanded the preparation about antibodies created Throughout life cycle of this parasite [22]. A portion investigations bring turned out intense impact of $n$. Sativa extracts on the protoscolices about hydatid cysts [23]. 
Nanoparticle engineering got to be you quit offering on that one strategy putting forth An profitable device should new pill conveyance methods, Hosting those characters for regulated release, safe serum levels for dynamic parts from enzymatic alternately Ecological corruption What's more internal maintenance. Nanoparticle manufacturing techniques apply with an extensive variety about medications [25]. Chitosan (CS) will be An biodegradable common polymer with great possibility to pharmaceutical provisions owing with its biodegradability, biocompatibility, non-toxicity, Furthermore mucosal adhe-sion [25].

Chitosan-based nanoparticles are likewise utilized in the medication for cancer, gastrointestinal diseases, pulmonary diseases, medication conveyance of the cerebrum Also visual contamination [26]. In this ponder we attempted on have more light with respect to n. Sativa impact around hydatid growth in vivo Possibly as monotheray alternately consolidated with Albendazole and its viability when stacked around chitosan nanoparticles whichever Concerning illustration monotheraby alternately joined together with Albendazole.

In this consider we accounted for Albendazole impact with respect to hydatid growth which spoke to Eventually Tom's perusing diminishing in the span Furthermore weight of the hydatid growth. Those percent for decrease done growth measure arrived at $47 \%$ for one assembly dealt with with Albendazole. The effects need aid Previously, parallel with (24) who accounted for that Albendazole needed useful impact for alveolar growth extent and diminished its measure by $78 \%$ Previously, aggregation from claiming mice approached with $150 \mathrm{mg}$ for Albendazole. [27] accounted for that Albendazole might have been additional successful over mebendazole , but its viability arrived at $97 \%$ this percent might be expected to separate defeat for organization, different measurements utilized and span from claiming its organization. Those impact about Albendazole on the hydatid growth might be expected to its parasitostatic instead of An parasitocidal effect, especially against e. Multilocularis lesionsas accounted Toward [28].

Our outcomes indicated also great viability for NSO Similarly as it brought about diminishment for hydatid cysts' sizes Furthermore weights clinched alongside one assembly approached with NSO alone Also no hydatid growth might have been found Previously, assembly approached with NSO stacked on chitosan nano. These effects are in parallel with that accounted for by [28] who accounted for that n. Sativa extricate may be more powerful over p. Granatum peel extricate in regards to scolicidal impact Previously, hydatid growth.

Late investigations need indicated that accompanying organization for $\mathrm{ABZ}$ for sure medications need a synergistic impact. Including metformin should traditional medication for ABZ (an antidiabetic drug) need expanded those viability about $\mathrm{ABZ}$ in vitro Furthermore in vivo (mouse models) [29]. Mefloquine consolidated medicine appears a guaranteeing combination, with outcomes marginally better than monotherapy with ABZ [30]. In this consider ABZ-NSO demonstrated slight increment to Albendazole viability Be that this Contrast might have been non statistically huge. In this consider the viability from claiming Albendazole Furthermore n. Sativa and its blending expanded At stacked on chitosan nanoparticles spoken to Eventually Tom's perusing finish nonattendance of the growth to compass $100 \%$ viability ,this implies that chitosan nanoparticles required incredible impact The point when any drug (Albendazole, NSO Furthermore combined)loaded on it. This build On pills viability is because of that chitosan nanoparticles moved forward those pills conveyance framework will tissues What's more progressed those pharmacokinetic about these medications. These comes about need aid in understanding with [25]who accounted for that chitosan microsphere need expanded those viability from claiming albendazole when it is utilized Similarly as pill conveyance framework.

Our outcomes were in line with that accounted Toward Nassef et al 2019[ 31] who accounted for that there might have been huge decrease for hydatid growth and weight Previously, aggregation approached with albendazole Be that as its viability expanded The point when stacked once silver [32] have showed that ABZ lipid nanocapsules (ABZ-LNCs) are that's only the tip of the iceberg compelling over ABZ On vivo, clinched alongside e. Granulosus contaminated mice, to oral organization.

Conclusion: Our study uncovered that there may be impact about nigella sativa oil and albendazole Also their consolidation looking into tentatively hydatid growth contaminated mice. The utilization for chitosan nanoparticles expanded the pill conveyance framework to tissues. Additional investigations looking into chitosan nanoparticles Previously, hydatid growth illness Possibly in vitro alternately in vivo need aid required.

\section{References}

[1] P.R. Torgerson, C.M. Budke, Echinococcosis-An International Public Health Challenge. Research in Veterinary Science, Vol. 74, PP.191-202. 2003.

[2] E. Brunetti , P.Kern , D.A. Vuitton,Expert consensus for the diagnosis and treatment of cystic and alveolar echinococcosis in humans[J]. Acta Trop, Vol.114 (1), PP. 1-16. 2010.

[3] R.W. Ammann , J. Eckert Cestodes, echinococcus. Gastroenterol Clin North Am, Vol.25(3), PP. 655689.1996.

[4] E. Brunetti, P. Kern, D.A.Vuitton, Expert consensus for the diagnosis and treatment of cystic and alveolar echinococcosis in humans[J]. Acta Trop, Vol.114 (1), PP. 1-16. 2010.

[5] A. Rafiei, F. Asgarian, M. Rahdar, A. Jelowdar M. Sabaghan , Experimental hydatid cyst development in different breeds of mice: A reevaluation- Biomedical Research Vol. 28, PP. 4. 2017.

[6] V. Velasco-Tirado, M. Alonso-Sardón, A. lopezbernus, A. Romero-Algeria, F. J. Burguillo, A. Muro, ...\& M. Belhassen-García, Medical treatment of 
cystic echinococcosis: systematic review and metaanalysis. BMC Infectious Diseases Vol.18,PP.306.2018.

[7] M. Zibaei, A. Sarlak, B. Delfan, B. Ezatpour, A. Azargoon, Scolicidal effects of Olea europaea and Satureja khuzestanica extracts on protoscolices of hydatid cysts. Korean J Parasitol, Vol. 50(1), PP. 53-56. 2012.

[8] M. Labsi , L. Khelifi , D. Mezioug , I. Soufli ,C. Touil-Boukoffa

Antihydatic and immunomodulatory effects of Punica granatum peel aqueous extrat in

a murine model of echinococcosis.Asian Pac J Trop Med,Vol. (3), PP.211-20. 2016.

[9] M. Amri , S.A. Aissa , H. Belguendouz , D. Mezioug . C Touil-Boukoffa In vitro antihydatic action of IFNgamma is dependent on the nitric oxide pathway.J Interferon Cytokine Res, Vol. 27(9), PP.781-7. 2007.

[10] S.M. Sadjjadi , M.R. Zoharizadeh, M.R. Panjeshahin In vitroscreening of differentAllium sativumextracts on hydatid cystsprotoscoleces. J Invest Surg, Vol.21(6), PP.318-322.2008.

[11] K.M. Al-Qaoud, S.K. Abdel-Hafez The induction of $\mathrm{T}$ helper type 1 response by cytokine gene transfection protects mice against secondary hydatidosis . ParasitolRes Vol. 102(6), PP.1151-5. 2008.

[12] K.M. Sharafeldin, The physiological impact of ginger, Zingiberofficinale and black seed oil, Nigella sativa L. as medicinal plants in gamma-irradiated rats. Egypt. J. Exp. Biol. (Zoo.),Vol. 11, PP. 185 - 192. 2015.

[13] M.F.M. Soliman, N.S. El-Shenawy, Evaluationof the protective effect of two antioxidative agents inmice experimentally infected with Schisto somama nsoni: Hae matological and histopathological aspects. Pak. J. boil, Vol.6, PP.887897. 2003.

[14] Z. Atayi , H. Borji , M. Moazeni , M. Saboor Darbandi Mand Heidarpour

Zataria multiflora would attenuate the hepatotoxicity of longterm albendazole treatment in mice with cystic echinococcosis.Parasitol Int., Vol.67(2),PP.184-187. 2018.

[15] Y. Ohya, M. Shiratani, H. Kobayashi , T. Ouchi. Release behaviour of 5-fluorouracil from chitosan-gel nanospheres immobilizing 5-fluorouracil coated with polysaccharides and their cell specific cytotoxicity. Journal of Macromolecular Science Part A, Vol.31(5), PP.629-642. 1994.

[16] M.A. Urrea-París, M.J. Moreno, N Casado, F. Rodríguez-Caabeiro Relationship between the efficacy of praziquantel treatment and the cystic

differentiation in vivo of Echinococcus granulosus $\mathrm{m}$ etacestode.Parasitol Res, Vol.88(1), PP.26-31. 2002.

[17] G.V. Ullio Gamboa, P.E. Pensel, M.C. Elissondo, S.F. Sanchez Bruni, J.P. Benoit, S.D.Palma, Albendazole -lipid nanocapsules: Optimization, characterization and chemoprophylactic efficacy in mice infected with Echinococcus granulosus. Experimental Parasitology, Vol. 198, PP.79-86.2019.

[18] K. Daniel- Mwambete, S. Torrado, C. CuestaBandera, F. Ponce-Gordo, J.J., The effect of solubilization on the oral bioavailability of three benzimidazole carbamate drugs [J]. Int $\mathrm{J}$ pharm, Vol.19272(1-2),PP.29-36,2004.

[19] P. Brunetti E, Kern, D.A. Vuitton Expert consensus for the diagnosis and treatment of cystic and alveolar echinococcosis in humans[J]. Acta Trop, Vol.114 (1): , PP.1-16.2010.

[20] R. Issa, Using Nigella sativa (Habbet ElBaraka) in treatment of some parasitic diseases. Egypt J Med Sci, Vol. 24(1-2), PP. 435-446.2003.

[21] R. Ullah, Rehman. , M.F. Zafeer, L. Rehman, Y.A. Khan, M.A. Khan, Anthelmintic A potential of thymoquinone and curcumin on Fasciola gigantica. PLoS One, Vol. 12(2), PP. 410-320. 2017

[22] N.M. Abu El Ezz Effect of Nigella sativa and Allium cepa oils on Trichinella spiralis in experimentally infected rats. J Egypt Soc Parasitol, Vol. 35(2), PP. 511-523. 2005.

[23] H. Mahmoudvand, A. Asadi, M.F. Harandi, F. Sharififar, S.Jahanbakhsh, E.S. Dezaki In vitro lethal effects of various extracts of Nigella sativa seed on hydatid cyst protoscoleces. Iran J Basic Med Sci, vol 17(12), PP. 1001-1006. 2014.

[24] M. Abulaihaiti, W .Wu X-, L. Qiao, , H.W Zhang, N. Aduwayi,) Efficacy of AlbendazoleChitosan Microsphere-based Treatment for Alveolar Echinococcosis in Mice. PLoS Negl TropDis Vol. 9(9), PP. 133-150. 2015.

[25] K. Nagpal, S.K. Singh, D.N. Mishra Chitosan nanoparticles: a promising system in novel drug delivery. Chemical and Pharmaceutical Bulletin Vol.58(11),PP.1423-1430. 2010.

[26] M.A. Mohammed, J.T.M. Syeda, K.M. Wasan, E.K. Wasan An Overview of Chitosan Nanoparticles and Its Application in Non- Parenteral Drug Delivery. Pharmaceutics vol 9(4), PP.1405-1410. 2017.

[27] E. Ismail, , M. Saad, A. Elsadig, Effect of Albendazole and Mebendazole on Hydatid Cyst of Mice. Open Journal of Epidemiology, Vol.7,PP. 3073162017.

[28] D.A. Vuitton, S.Bresson-Hadni Alveolar echinococcosis:an evaluation of therapeutic strategies.Expert OpinO rphan Drugs Vol.7,PP. 307316.2014.

[29] D. Gorgas, N. Marreros, R. Rufener, A. Hemphill, B.Lundström-Stadelmann To see or not to see: Non-invasive imaging for improved readout of drug treatment trials in the murine model of secondary alveolar echinococcosis. Parasitology, vo;.144(7), PP.937-944.2017.

[30] J.A. Loos, V.A. Dávila, C.R. Rodrígues, R. Petrigh, J.A. Zoppi, F.A. Crocenzi, Metformin exhibits preventive and therapeutic efficacy against experimental cystic echinococcosis. PLoS Neglected Tropical Diseases. Vol. 11(3), PP.25-35, 2017. 
[31] N. Nassef, A. Saad, N. Harba, V. N. Beshay , M. A. Gouda , S. S. Shendi, A. S.Mohamed evaluation of the therapeutic efficacy of albendazole-loaded silver nanoparticles against Echinococcus granulosus infection in experimental miceJournal of Parasitic Diseases Vol.43, PP.658671.2019 .
[32] G.V. Ullio Gamboa, P.E. Pensel , M.C. Elissondo, S.F. Sanchez Bruni, J.P. Benoit, S.D. Palma, Albendazole-lipid nanocapsules: Optimization, characterization and chemoprophylactic efficacy in mice infected with Echinococcus granulosus. Experimental Parasitology, Vol. 198 , PP.79-86. 2019. 